\title{
Physiological and proteomics insights into salt tolerance of two Jerusalem artichoke cultivars
}

\author{
Min Yang ${ }^{1,3} \cdot$ Xing Sun $^{2} \cdot$ Juhua Zhu $^{1} \cdot$ Yenan Liu $^{1,3} \cdot \mathrm{Ni}$ Chen $^{1,3} \cdot$ Gengmao Zhao $^{1,3}$ (D)
}

Received: 28 April 2020 / Accepted: 21 December 2020/Published online: 4 January 2021

(C) The Author(s) 2021

\begin{abstract}
Jerusalem artichoke (Helianthus tuberosus L.) is an insulin-containing crop, which has been paid an intensive attention in recent decades. Although, some progress has been made in the biochemistry of Jerusalem artichokes (JA), the inner adaptive mechanism of salt tolerance among JA varieties is still unclear. Elucidating salt-tolerant differences by integrated stress physiology and proteomics approach will provide comprehensive insights into their adaptive mechanism for various JA varieties, therefore serving for the large-scare cultivation in salt-affected marginal lands. JA seedlings were initially grown in half-strength Hoagland solution, and then exposed to 100 and $200 \mathrm{mM} \mathrm{NaCl}$ for 30 days. We found that salt stress decreased the plant height, root length, fresh and dry weight in both varieties, and the decreasing extents of N1 (Helianthus tuberosus var. N1) was greater than M1 (Helianthus tuberosus var. M1). Chloroplast ultrastructure in N1 was severely damaged, but appeared unaltered in M1. Also, N1 remained lower selective for $\mathrm{K}^{+}$over $\mathrm{Na}^{+}$, exhibiting more $\mathrm{Na}^{+}$accumulation in plant tissues compared to M1. Penetrating cutting-edge elementary proteomic results showed the regulation of protein expression in M1 was much more positive than in N1. Taken together, these results illustrated the considerable differences in adaption to saline environment between varieties.
\end{abstract}

Gengmao Zhao

seawater@njau.edu.cn

Min Yang

2018103011@njau.edu.cn

Xing Sun

xsun@chzu.edu.cn

Juhua Zhu

2013103015@njau.edu.cn

Yenan Liu

2017103010@njau.edu.cn

Ni Chen

2018803173@njau.edu.cn
College of Resources and Environmental Sciences, Nanjing Agricultural University, Nanjing 210095, Jiangsu Province, People's Republic of China

2 School of Biological Science and Food Engineering, Chuzhou University, Chuzhou 239000, Anhui Province, People's Republic of China

3 Jiangsu Provincial Key Lab of Marine Biology, Nanjing 210095, Jiangsu Province, People's Republic of China 


\section{Graphic abstract}

\section{Salt Tolerance Between JA Cultivars}

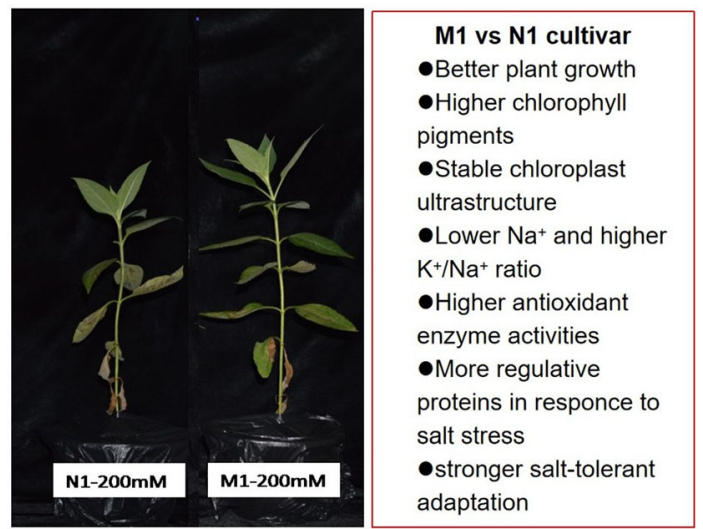

Keywords Antioxidant enzyme activity $\cdot$ Cellular ultrastructures $\cdot$ Ion homeostasis $\cdot$ Salt stress

$\begin{array}{ll}\text { Abbreviations } \\ \text { CAT } & \text { Catalase } \\ \text { Chl a } & \text { Chlorophyll a } \\ \text { Chl b } & \text { Chlorophyll b } \\ \text { GL } & \text { Granum lamella } \\ \text { JA } & \text { Jerusalem artichokes } \\ \text { M1 } & \text { Helianthus tuberosus var. M1 } \\ \text { MDA } & \text { Malondialdehyde } \\ \text { N1 } & \text { Helianthus tuberosus var. N1 } \\ \text { POD } & \text { Peroxidase } \\ \text { ROS } & \text { Reactive oxygen species } \\ \text { SOD } & \text { Superoxide Dismutase } \\ \text { TCA } & \text { Trichloroacetic acid } \\ \text { TChl } & \text { Total chlorophyll } \\ \text { TEM } & \text { Transmission electron microscopy }\end{array}$

\section{Introduction}

Salinity is a major problem affecting crop production all over the world: $20 \%$ of cultivated land in the world, and $33 \%$ of irrigated land, are salt-affected and degraded (Machado and Serralheiro 2017). Salt-affected soils occur in more than 100 countries worldwide, although varying from their extent of different places (Bui 2013). Recently, many plants have been intensely studied on their salt-tolerant processes, including physiological or molecular responses to salinity, aiming at well utilizing saline-alkali soil for crop production (Singh et al. 2012; Roy et al. 2014; Munns and Gilliham 2015).
JA is widely regarded with the relevant literature as moderate salt-tolerant plant, and it is rich in carbohydrates, of which 70-90\% is inulin (Newton et al. 1991; Zhao et al. 2010). Many studies documented that JA species had stronger ecological adaptability to cold, drought and salinity, which just complied with China government's concept of exploiting coastal saline soils for agricultural production (Zhao et al. 2010; Bhagia et al. 2018).

It has been reported that JA growth is generally inhibited by ionic toxicity, which can result in a little bit tube yield losses (Xue and Liu 2008), and some salt-tolerant mechanisms might play a vital role in compensating this adverse effects, including ion regionalization, fluctuations in antioxidant enzyme activity and osmotic adjustment under saline conditions (Yang et al. 2016; Long et al. 2009;). Additionally, salt resistance to plants is mainly controlled by polygenes, and this helps form newly synthesized or enhanced proteins, so-called salt-stress proteins which might be closely correlated to plant regulatory mechanisms (Duché et al. 2002). Recently, proteomics were widely used to analyze salt tolerance of many conventional plants (Eldakak et al. 2013; Aslam et al. 2017). However, it has not been applied to the study on the JA plant by far. Proteomics methodologies achieve rapid development within several years, and shift from two-dimensional gel electrophoresis (2-DE)-based approaches to SDS-PAGE or gelfree workflows in isotopic labeling techniques, nano-liquid chromatography, and high-resolution mass spectrometry, which provides a reliable analysis for salt-tolerant mechanism of plants for special purpose. The hypothesis of this paper is that the salt tolerance of JA plant has significant intraspecific differences and salt stress results in a series of adaptive responses in physiological and biochemical bases. 
The objective of this study was to elucidate the salttolerant mechanisms of two JAs at the physiological and proteomics level, thereby provided comprehensive insights into differences in adaptation to saline environments between the two JAs. This study was of great significance on the JA variety breeding and cultivation in salt-affected region for food industrial purpose.

Two JAs (Helianthus tuberosus var. N1 and Helianthus tuberosus var. M1) were long-term preserved in Jiangsu Provincial Key Lab of Marine Biology. N1 is tested as a moderate salt-tolerant variety which was widely cultivated in coastal saline land, while M1 is introduced from Russia in 2009. Prior to cultivation, JA tubers were cut in many nubbles with buds, then sterilized with $1.0 \mathrm{~g} \mathrm{~L}^{-1} \mathrm{HgCl}_{2}$ for $10 \mathrm{~min}$, rinsed thoroughly with distilled water and germinated into moist sand in an incubator at $25^{\circ} \mathrm{C}$. Emergening with 4th leaf, uniform JA seedlings were transplanted into plastic kegs and hold up by polyethylene lid through which plants were supported over the nutrient solution. There are three treatments of this experiment, including non salttreated $(0 \mathrm{mM}), 100 \mathrm{mM}$ and $200 \mathrm{mM} \mathrm{NaCl}$ addition treatments. Among treatments, a factorial setup was arranged on the basis of a completely randomised design with three replications. JA seedlings were exposed to salt solution when they were four-week old, and harvested after 30 days. While harvesting, plant samples were collected in two separate sets, one was used for determining the growth status and analysing ion composition of plant tissues, the other was for physiological and biochemical analysis, such photosynthetic pigments, antioxidant enzymes and proteome.

The plant height, root length and fresh weight were measured to according to Lu (2000), plant dry weight (DW) and the relative water content (RWC) were measured to according to Smart and Bingham (1974). The chlorophyll a (Chl a), chlorophyll b (Chl b) and total chlorophyll
(tChl) concentrations were calculated according to Litchenthaler (1987), and the total carotenoids were analysed as described by Mencarelli and Saltveit (1988).CAT and POD activity was assayed according to the method described by Bradford (1976), Bergmeyer and Bernt (1974) and Kwak et al. (1995). Total proteins were extracted from JA leaves by a conventional trichloroacetic acid (TCA)/ acetone method with some embellishment (Chen et al. 2011; Thiede et al. 2013).The data and comparative analysis between samples were performed by the soft of PDQuest7.2 (GE Healthcare Life Science). The mean values were calculated according to three replicates of plant samples by Microsoft Excel for Windows, and the standard error of means was generated through SPSS15.0 software. Two-way ANOVA was further applied to determine their significance of treatments. Also, the Duncan's new multiple range test $(P<0.05)$ was adopted for data statistics in this research.

There were phenotypic differences between the two JAs immersed in the different concentrations of salt solution (Fig. 1). Salt stress exerted a negative impact on the plant fresh weight compared to the control, decreased by approximately $23.7 \%$ and $16.5 \%$ in $100 \mathrm{mM} \mathrm{NaCl}$ treatment, $42.5 \%$ and $34.2 \%$ in $200 \mathrm{mM} \mathrm{NaCl}$ treatment for $\mathrm{N} 1$ and M1, respectively (Table 1). And there was the same trend which was clearly observed for the plant dry weight. The plant height and root length were also influenced by salt stress, whilst their values of $\mathrm{N} 1$ were considerably lower than M1. Moisture contents of N1 showed a significant reduction in $200 \mathrm{mM} \mathrm{NaCl}$ treatment; however those of M1 remained unchanged. Those results indicated that M1 had a stronger resistance to salt stress compared to N1.

Figure 2 shows for M1, Chl a decreased to some extent merely under $200 \mathrm{mM} \mathrm{NaCl}$ stress, whilst $\mathrm{Chl} b$ and $\mathrm{T}$ chl remained unchanged under the tested salinities, and Car, however, increased with increasing salinities. For N1, the
Fig. 1 Representative photographs of the two $\mathrm{s}$ showed a growth reduction N1 and M1 with increasing salt stress levels. Plants were grown in hydroponic solution and treated with 0 (control), $100 \mathrm{mM} \mathrm{NaCl}$, and $200 \mathrm{mM}$ $\mathrm{NaCl}$, respectively for 30 days

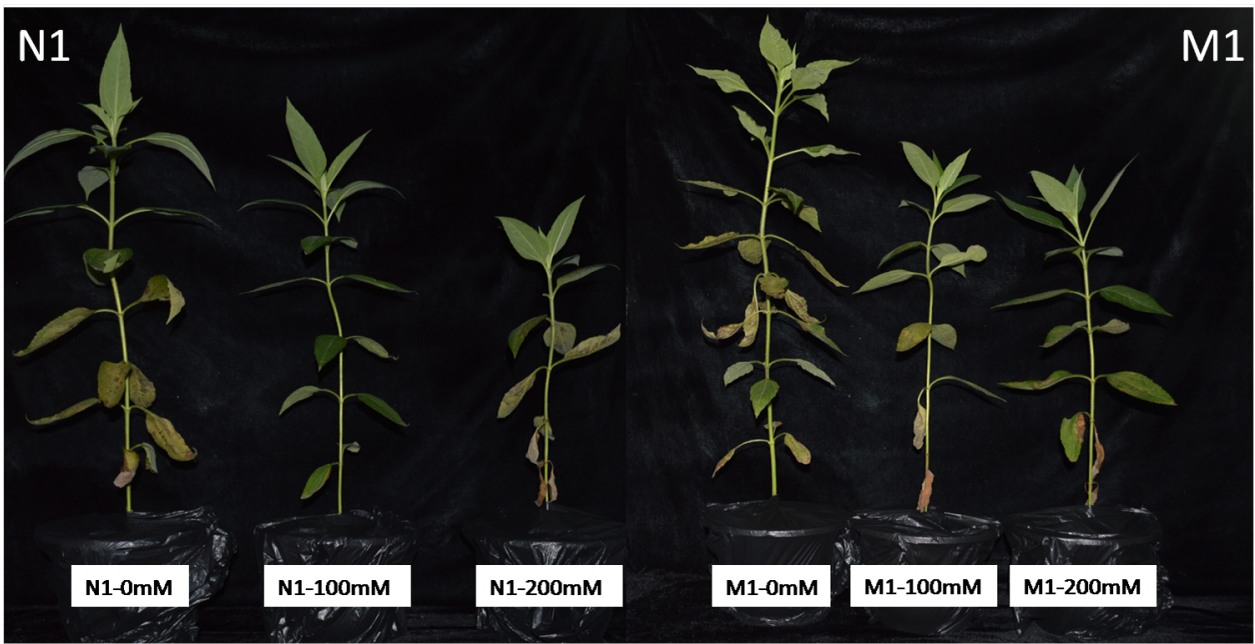


Table 1 Effect of $\mathrm{NaCl}$ stress on the growth of two JA cultivars

\begin{tabular}{lllllll}
\hline $\mathrm{NaCl}(\mathrm{mM})$ & & Height $(\mathrm{cm})$ & Root length $(\mathrm{cm})$ & Fresh weight $(\mathrm{g})$ & Dry weight $(\mathrm{g})$ & Moisture content $(\%)$ \\
\hline 0 & $\mathrm{~N} 1$ & $76.10 \pm 1.95 \mathrm{a}$ & $36.23 \pm 1.41 \mathrm{a}$ & $85.60 \pm 3.53 \mathrm{a}$ & $10.98 \pm 0.80 \mathrm{a}$ & $87.18 \pm 0.69 \mathrm{a}$ \\
& $\mathrm{M} 1$ & $76.90 \pm 3.24 \mathrm{a}$ & $35.97 \pm 1.06 \mathrm{a}$ & $89.23 \pm 2.72 \mathrm{a}$ & $11.29 \pm 0.50 \mathrm{a}$ & $87.33 \pm 0.82 \mathrm{a}$ \\
100 & $\mathrm{~N} 1$ & $66.20 \pm 2.82 \mathrm{~b}$ & $30.60 \pm 1.52 \mathrm{~b}$ & $65.36 \pm 1.18 \mathrm{c}$ & $8.71 \pm 0.19 \mathrm{c}$ & $86.66 \pm 0.27 \mathrm{a}$ \\
& $\mathrm{M} 1$ & $69.10 \pm 3.18 \mathrm{~b}$ & $32.43 \pm 1.15 \mathrm{ab}$ & $74.49 \pm 2.41 \mathrm{~b}$ & $9.40 \pm 0.14 \mathrm{~b}$ & $87.38 \pm 0.24 \mathrm{a}$ \\
200 & $\mathrm{~N} 1$ & $49.37 \pm 2.54 \mathrm{~d}$ & $25.27 \pm 1.65 \mathrm{c}$ & $48.81 \pm 3.24 \mathrm{c}$ & $7.43 \pm 0.52 \mathrm{~d}$ & $84.77 \pm 0.62 \mathrm{~b}$ \\
& M1 & $56.13 \pm 3.25 \mathrm{c}$ & $29.73 \pm 2.21 \mathrm{~b}$ & $58.69 \pm 3.77 \mathrm{~d}$ & $8.41 \pm 0.38 \mathrm{c}$ & $85.67 \pm 0.63 \mathrm{a}$
\end{tabular}

Significant differences $(P \leq 0.05)$ between the $\mathrm{NaCl}$ treatments are indicated by different letters. Data are presented as the means $\pm \mathrm{SD}(\mathrm{n}=3)$
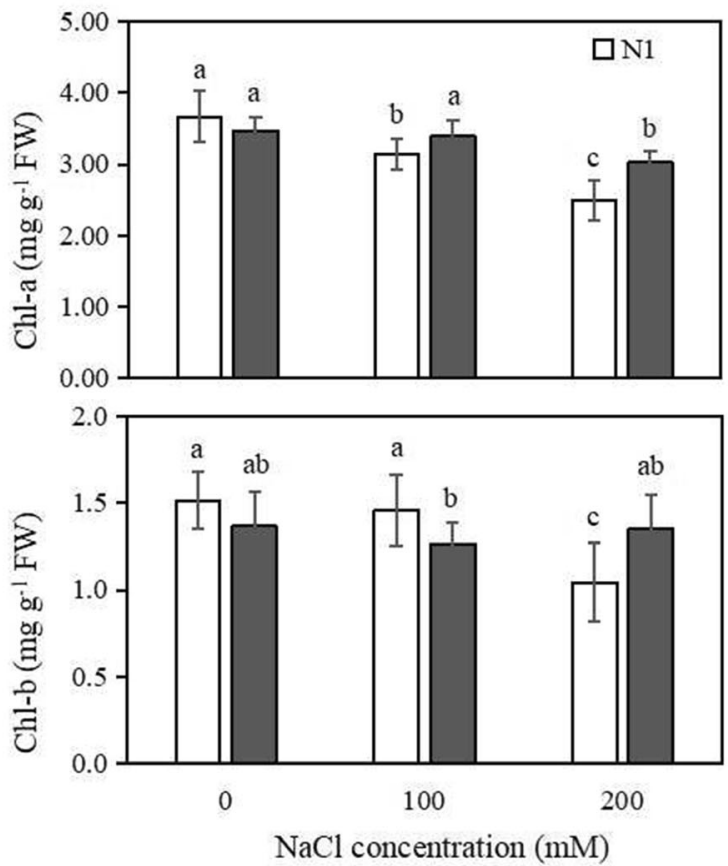

Fig. 2 Effect of $\mathrm{NaCl}$ stress on chlorophyll a, chlorophyll b, total chlorophyll and carotenoid contents in leaves of JA s. The values are presented as the means \pm standard error $(\mathrm{SE}) ; \mathrm{n}=3$ for all groups.

result almost reversed, showing a significant reduction in Chl a, Chl b and T chl under successively strengthened salt stresses; however, the maximum value of Car contents was observed in the $100 \mathrm{mM}$ other than $200 \mathrm{mM} \mathrm{NaCl}$ treatments. Additionally, the levels of chlorophyll pigments were remarkably higher in M1 than in N1, no matter if JAs were under salt stress or not, suggesting M1 displayed stronger photosynthetic capacity than N1 against salinity stress.

To further elucidate the differences of photosynthetic capacities between the two JAs subjected to salt stress, the ultrastructure changes were determined by transmission electron microscopy (TEM) (Fig. 3). The chloroplasts in control were located in mesophyll and parenchyma cells, containing large starch grains (SG), whereas in the salt-

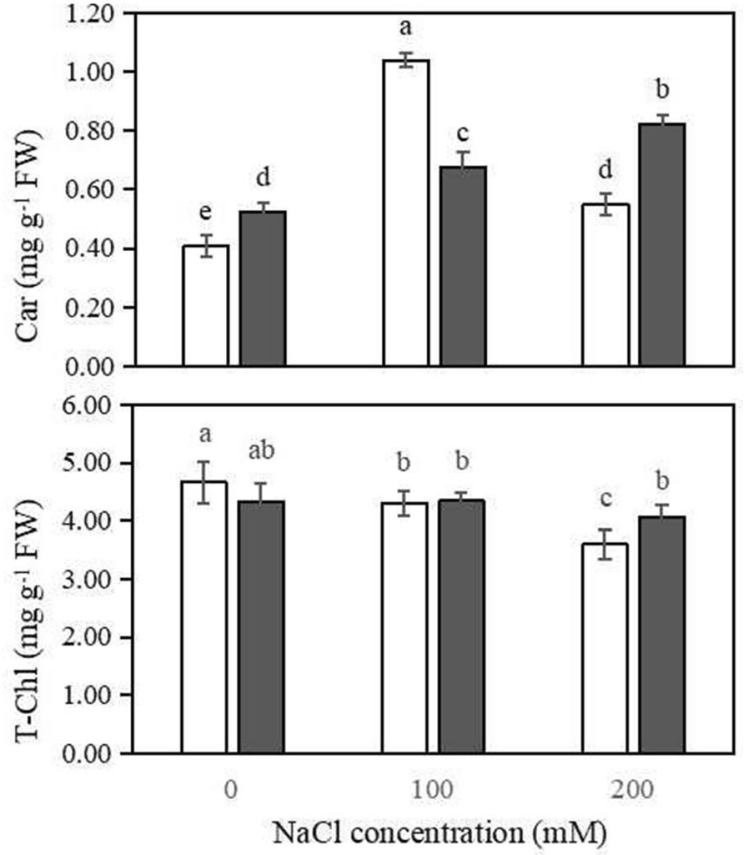

The bars represent the SE. Bars with the same letter are not significantly different, denoted by $P<0.05$ according to Duncan's multiple range tests

treated plants, chloroplasts showed somewhat degradation. Overall, N1 suffered severe alteration of the chloroplast ultrastructure by salt stress, but M1 remained relatively stable, showing that the thylakoidal membranes in N1 disorganized with more swelling and curling than M1 at the same salt concentration. The cell plasmolysis occurred in two JAs, which became increasingly rigorous in conjunction with increasing salinity. And for the two JAs, the ultrastructural response to salinity was that salinity scarcely influenced the thylakoids and perturbed the granum lamella (GL) in M1, whereas GL numbers in N1 were reduced and the thylakoid membrane was also decreased markedly by salt stress.

Generally, superfluous $\mathrm{Na}^{+}$uptake by JA plants caused retardant plant growth, which was shown in Table 2. For 


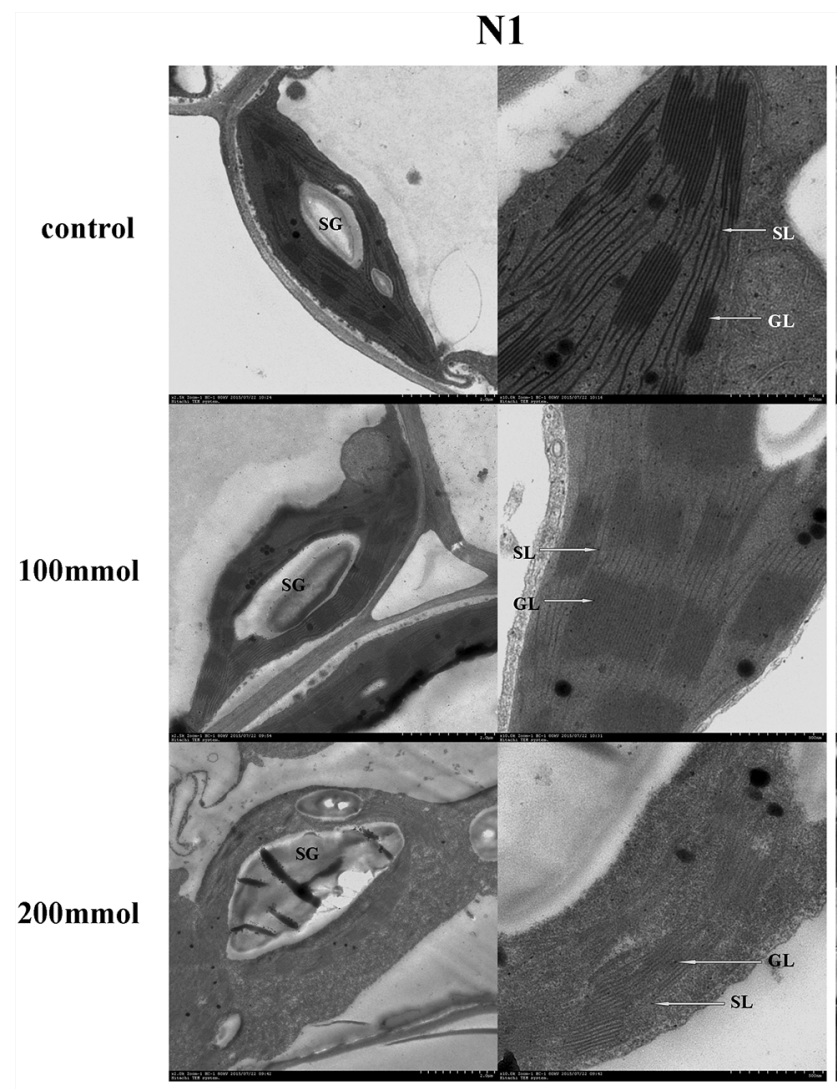

Chloroplast

Thylakoids

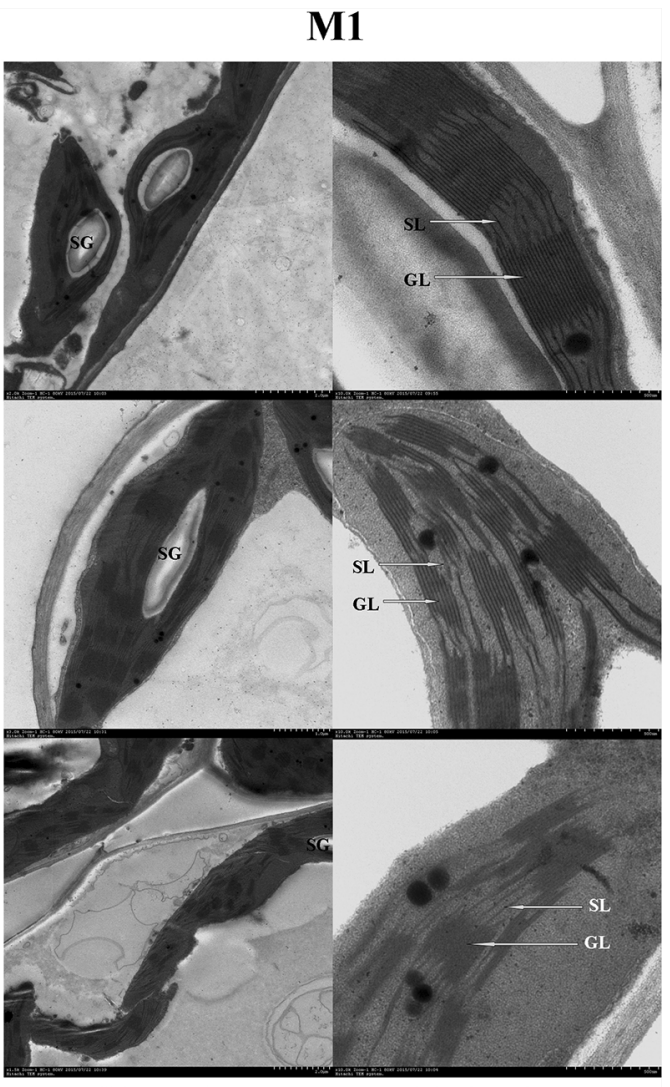

Chloroplast
Thylakoids

Fig. 3 Effect of salt stress on chloroplast ultrastructure in leaves of $\mathrm{N} 1$ and $\mathrm{M} 1 \mathrm{~s}$. Three salinity gradients were used: $0 \mathrm{mM}$ (control), $100 \mathrm{mM}$, and $200 \mathrm{mM}$. $S L$ stroma lamella, $G L$ grana lamellae, $S G$ starch grain

the two JAs, $\mathrm{Na}^{+}$was markedly increased with increasing salinity, and it was mostly accumulated in the roots, followed by the stems and then in the leaves.

Instead, $\mathrm{Mg}^{2+}, \mathrm{Ca}^{2+}, \mathrm{K}^{+}$concentration in plant tissues declined with increasing salinity. Superfluous $\mathrm{Na}^{+}$entering into JA tissues had a negative effect on $\mathrm{K}^{+}$uptake by plant roots, resulted in a relatively lower $\mathrm{K}^{+} / \mathrm{Na}^{+}$ratio. There was no significant difference for $\mathrm{K}^{+} / \mathrm{Na}^{+}$ratio in the plant tissues at low-concentration of salt stress $(100 \mathrm{mM})$, nevertheless $\mathrm{M} 1$ possessed better capacity to regulate $\mathrm{K}^{+} / \mathrm{Na}^{+}$ homeostasis than $\mathrm{N} 1$ at high-concentration of salt stress (200 mM).

Figure 4 shows $100 \mathrm{mM} \mathrm{NaCl}$ significantly elevated the SOD, POD and CAT activities of JA plant, but $200 \mathrm{mM}$ $\mathrm{NaCl}$ had exactly the reverse effect. The SOD activity in M1 was found to be considerably higher than that in N1 in $200 \mathrm{mM} \mathrm{NaCl}$ treatment, whereas no differences were observed in $100 \mathrm{mM} \mathrm{NaCl}$ treatment. The POD activity response to salt stress in both JA s had the same trend with the SOD activity. The CAT activity, however, was obviously activated in $100 \mathrm{mM} \mathrm{NaCl}$ treatment, but was severely inhibited in $200 \mathrm{mM} \mathrm{NaCl}$ treatment for the two JA s. Malondialdehyde (MDA), measured as TBARS, increased consistently with increasing level of salinity in two s, therefore indicating a sharp increase in lipid peroxidation. High salinity conditions resulted in increases in MDA by $72.9 \%$ and $44.3 \%$ in N1 and M1, respectively, from which we can surmise that more severe lesions occurred in the biological membranes of $\mathrm{N} 1$.

Variant protein spots of double varieties were shown in Fig. 5. The protein spots detected in all three replicates of silver-stained gels were analysed with an image scanner and the average response content of every spot protein was then calculated. In the protein analysis of N1, the expression of greater than 39 proteins was markedly reduced and 9 proteins were significantly increased. In M1, approximately 30 proteins decreased and 18 proteins increased. Further analysis revealed that plots 5306, 6409, 4306, 3308 increased with increasing salinity, whereas plots 2609 , 5607, 5510 as well as ten other plots consistently decreased. Of those, plot 6309 showed the greatest negative correlation with salinity. Previously described protein plots likely had similar effects on the regulation of salt stress responses. Comparatively, the regulation of protein expression in M1 was much more positive than in N1. 
Table 2 Effect of $\mathrm{NaCl}$ stress on $\mathrm{Mg}^{2+}, \mathrm{Ca}^{2+}, \mathrm{Na}^{+}$and $\mathrm{K}^{+}$absorption of two JA cultivars

\begin{tabular}{|c|c|c|c|c|c|c|c|}
\hline \multirow{2}{*}{$\begin{array}{l}\mathrm{NaCl} \\
(\mathrm{mM})\end{array}$} & \multirow[t]{2}{*}{ s } & \multicolumn{3}{|c|}{$\mathrm{Mg}^{2+}\left(\mathrm{mg} \mathrm{g}^{-1} \mathrm{DW}\right)$} & \multicolumn{3}{|c|}{$\mathrm{Ca}^{2+}\left(\mathrm{mg} \mathrm{g}^{-1} \mathrm{DW}\right)$} \\
\hline & & Leaf & Stem & Root & Leaf & Stem & Root \\
\hline \multirow[t]{2}{*}{0} & N1 & $3.44 \pm 0.10 \mathrm{~b}$ & $1.71 \pm 0.16 \mathrm{a}$ & $4.46 \pm 0.45 b$ & $27.47 \pm 2.17 \mathrm{a}$ & $17.05 \pm 0.59 b$ & $23.32 \pm 1.82 \mathrm{a}$ \\
\hline & M1 & $3.16 \pm 0.28 b c$ & $1.58 \pm 0.30 \mathrm{a}$ & $3.38 \pm 1.10 \mathrm{c}$ & $27.18 \pm 1.67 \mathrm{a}$ & $16.45 \pm 0.68 b$ & $22.31 \pm 2.26 a$ \\
\hline \multirow[t]{2}{*}{100} & N1 & $4.64 \pm 0.63 a$ & $0.78 \pm 0.11 b$ & $2.32 \pm 0.22 \mathrm{~d}$ & $19.63 \pm 1.15 b$ & $18.84 \pm 0.78 \mathrm{a}$ & $17.88 \pm 1.38 b$ \\
\hline & M1 & $3.73 \pm 0.37 b$ & $0.61 \pm 0.20 \mathrm{~b}$ & $4.34 \pm 0.32 b$ & $19.29 \pm 2.03 b$ & $13.90 \pm 0.57 \mathrm{c}$ & $17.06 \pm 1.57 \mathrm{~b}$ \\
\hline \multirow[t]{2}{*}{200} & $\mathrm{~N} 1$ & $3.54 \pm 0.19 b$ & $0.74 \pm 0.05 b$ & $5.48 \pm 0.19 a$ & $17.29 \pm 0.34 b$ & $14.92 \pm 0.74 \mathrm{c}$ & $12.76 \pm 0.96 \mathrm{c}$ \\
\hline & M1 & $2.56 \pm 0.38 \mathrm{c}$ & $0.71 \pm 0.09 \mathrm{~b}$ & $1.49 \pm 0.06 \mathrm{e}$ & $19.05 \pm 1.96 \mathrm{~b}$ & $10.52 \pm 0.70 \mathrm{~d}$ & $8.47 \pm 0.93 \mathrm{~d}$ \\
\hline \multirow{2}{*}{$\begin{array}{l}\text { Treatment } \\
(\mathrm{mM})\end{array}$} & \multirow[t]{2}{*}{$\mathrm{s}$} & \multicolumn{3}{|c|}{$\mathrm{Na}^{+}\left(\mathrm{mg} \mathrm{g}^{-1} \mathrm{DW}\right)$} & \multicolumn{3}{|l|}{$\mathrm{K}^{+}\left(\mathrm{mg} \mathrm{g}^{-1} \mathrm{DW}\right)$} \\
\hline & & Leaf & Stem & Root & Leaf & Stem & Root \\
\hline \multirow[t]{2}{*}{0} & N1 & $1.44 \pm 0.11 \mathrm{e}$ & $0.73 \pm 0.10 \mathrm{c}$ & $6.31 \pm 0.63 c$ & $46.35 \pm 6.21 \mathrm{ab}$ & $65.37 \pm 11.11 \mathrm{a}$ & $32.20 \pm 6.09 \mathrm{ab}$ \\
\hline & M1 & $1.11 \pm 0.13 \mathrm{e}$ & $1.17 \pm 0.07 \mathrm{c}$ & $7.24 \pm 0.95 \mathrm{c}$ & $43.94 \pm 5.46 \mathrm{abc}$ & $66.99 \pm 6.09 a$ & $34.38 \pm 8.55 \mathrm{a}$ \\
\hline \multirow[t]{2}{*}{100} & N1 & $6.81 \pm 0.57 \mathrm{c}$ & $2.01 \pm 0.12 b$ & $11.06 \pm 1.01 \mathrm{~b}$ & $50.83 \pm 3.98 \mathrm{a}$ & $42.28 \pm 5.50 \mathrm{bc}$ & $28.71 \pm 5.81 \mathrm{ab}$ \\
\hline & M1 & $5.83 \pm 0.46 \mathrm{~d}$ & $1.88 \pm 0.32 b$ & $12.32 \pm 2.74 b$ & $37.51 \pm 2.19 \mathrm{c}$ & $41.18 \pm 3.06 \mathrm{bc}$ & $27.57 \pm 3.57 \mathrm{ab}$ \\
\hline \multirow[t]{2}{*}{200} & N1 & $8.81 \pm 0.76 \mathrm{a}$ & $2.54 \pm 0.47 \mathrm{a}$ & $18.10 \pm 1.42 \mathrm{a}$ & $42.37 \pm 0.77 b c$ & $30.27 \pm 8.04 \mathrm{c}$ & $33.61 \pm 2.55 \mathrm{ab}$ \\
\hline & M1 & $7.66 \pm 0.18 b$ & $2.34 \pm 0.38 \mathrm{ab}$ & $16.78 \pm 2.15 \mathrm{a}$ & $36.09 \pm 4.55 \mathrm{c}$ & $45.49 \pm 3.15 b$ & $22.92 \pm 3.57 b$ \\
\hline \multirow{2}{*}{$\begin{array}{l}\text { Treatment } \\
(\mathrm{mM})\end{array}$} & & $\mathrm{s}$ & & & & & \\
\hline & & & $\mathrm{L}$ & & Stem & & Root \\
\hline 0 & & N1 & & $\pm 3.03 \mathrm{~b}$ & $89.35 \pm$ & & $5.09 \pm 0.69 a$ \\
\hline & & M1 & & $\pm 5.59 a$ & $57.46 \pm$ & & $4.89 \pm 1.68 \mathrm{a}$ \\
\hline 100 & & N1 & & $\pm 0.81 \mathrm{c}$ & $21.01 \pm$ & & $2.61 \pm 0.56 b$ \\
\hline & & M1 & & $\pm 0.30 \mathrm{c}$ & $22.10 \pm$ & & $2.31 \pm 0.59 b$ \\
\hline 200 & & N1 & & $\pm 0.43 \mathrm{c}$ & $11.82 \pm$ & $52 \mathrm{~d}$ & $1.38 \pm 0.11 \mathrm{~d}$ \\
\hline & & M1 & & $\pm 0.51 \mathrm{c}$ & $19.61 \pm$ & & $1.87 \pm 0.26 \mathrm{c}$ \\
\hline
\end{tabular}

Significant differences $(P \leq 0.05)$ between the $\mathrm{NaCl}$ treatments are indicated by different letters. Data are presented as the means $\pm \mathrm{SD}(\mathrm{n}=3)$

Therefore, analogous response mechanisms of JA to salt stress disclosed some divergent procedures.

Salinity did adversely affect the tested plant growth, including height, root length and fresh/dry weight (Table 1), although JA plant was generally considered as a moderate salt-tolerant species (Zhao et al. 2010). This phenomenon had also been found in many other crop species like wheat (Datta et al. 2009), soybean (Dolatabadian et al. 2011), canola (Tuncturk et al. 2011) and some halophytes (Akhzari et al. 2012). In this experiment, JA plant growth exhibited varying responses to $\mathrm{NaCl}$ stress among s. Overall, M1 grew relatively well than N1 under the salt-stressed conditions, demonstrating M1 had stronger salt-resistant capacity. This was mainly because, JA s suffered from salt stress were under moisture lose, resulting in the retardant plant growth rate. Therefore, plant moisture content could be regarded as an indicator characterizing salt tolerant capacity of JA plant.

The depression of photosynthesis due to salt stress is mainly ascribed to a reduction in chlorophyll content
(Ashraf and Harris 2004). In plants, the chlorophyll content of leaves is not only a straightforward, reflective and revealing index of plant photosynthetic capacity but also an important physiological index to measure the ability of salt resistance (Willekens et al. 1994). Salt stress also resulted in a reduction in chlorophyll of JA plant, which agreed with previous studies of salt-treated rice, sorghum and maize (Yilmaz and Kina 2008). But between JA s, M1 showed higher photosynthetic pigment contents in its leaves in comparison with $\mathrm{N} 1$.

It has been reported that salt stress causes membranes to swell, increases in plastoglobuli, changes in starch levels and the destruction of grana in many plants (Keiper et al. 1998; Hernandez et al. 1999). This phenomenon were analogous to those observed in chloroplasts of salt-treated N1 (Fig. 3). In contrast, M1 maintained inerratic grana with no swelling of thylakoid membranes in $100 \mathrm{mM}$ and $200 \mathrm{mM} \mathrm{NaCl}$ treatments, which indicated that M1 was a relatively salt-tolerant. On average, the photosynthetic organelle ultrastructures in M1 appeared to be well 

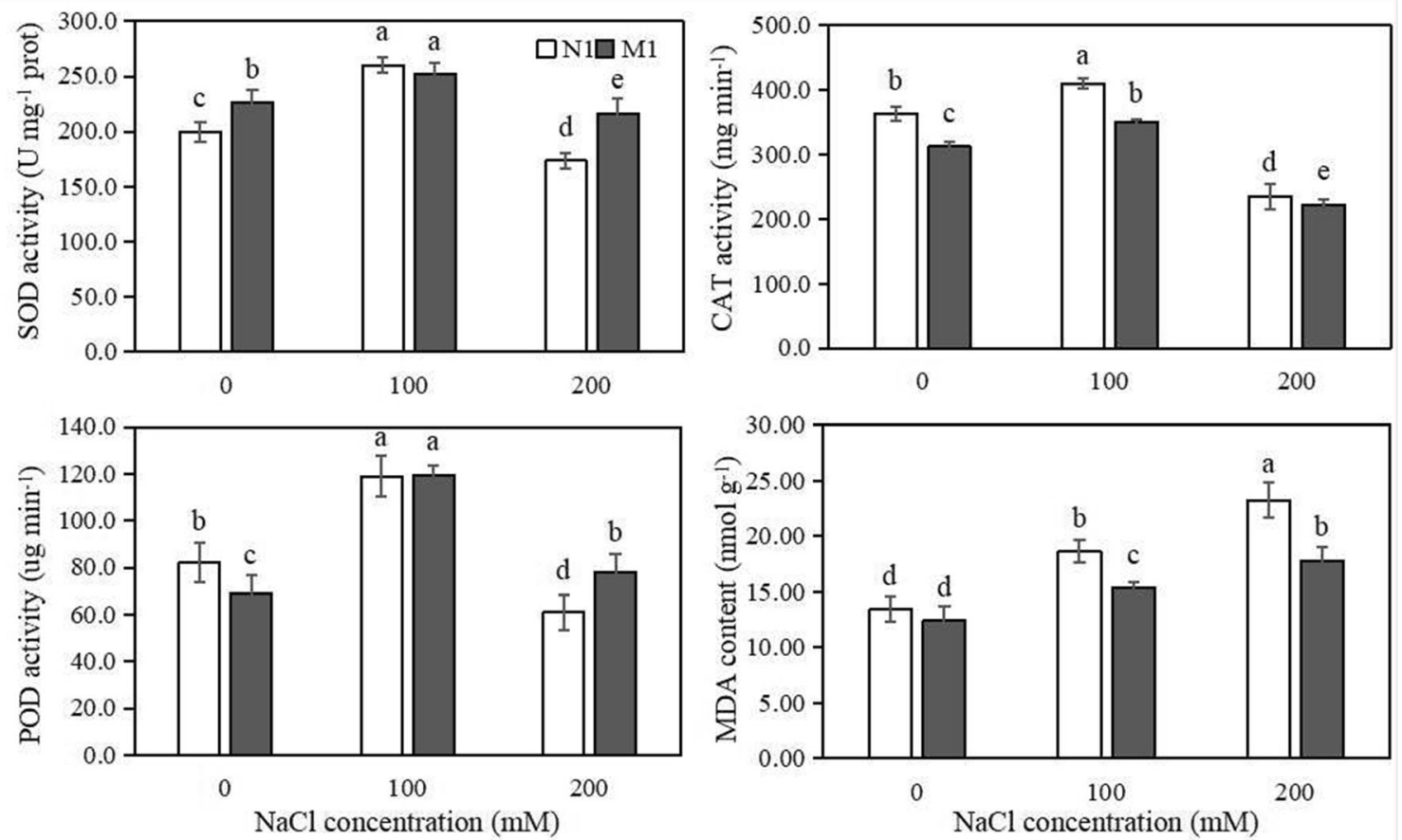

Fig. 4 Effect of $\mathrm{NaCl}$ stress on MDA content and SOD, CAT and POD activities in leaves of two JA s. The values are presented as the means \pm standard error (SE); $n=3$ for all groups. The bars represent

maintained under salt stress. Thus, M1 possessed more beneficial defense mechanisms against salt stress than N1.

When treated with high salinity, superfluous $\mathrm{Na}^{+}$ depolarizes the plasma membrane and the resultant outflow of $\mathrm{K}^{+}$can damage the membrane structure and then result in disorders of cell metabolism, which ultimately restrains plant growth (Shabala et al. 2003). According to Tester (Tester and Davenport 2003), the effects of salt stress on photosynthesis in plants include damage caused by the unbalance of ion absorption, and the water potential of osmotic stress reduction, etc. The regulation and distribution of ions in various plants parts and within cells is an indispensable characteristic of the mechanism of salt tolerance (Mahmoodzadeh et al. 2015) because the specific accumulation of $\mathrm{Na}^{+}$in tissues of plants was toxic and had been found to be one of the primary causes of reduced growth under salinity conditions. Such a distribution mode of inorganic cations decreased the osmotic potential of the root environment and guaranteed the natural physiological function and metabolism of the plant. Our studies showed a significant accumulation of $\mathrm{Na}^{+}$and substantial reduction of $\mathrm{Mg}^{2+}, \mathrm{K}^{+}, \mathrm{Ca}^{2+}$ in two JAs under higher salinity stress $(200 \mathrm{mM} \mathrm{NaCl})$. Clearly, osmotic adjustment capacity of M1 was greater than of N1, especially at high lever salt stress.

Under normal circumstances, plants have a large armament of antioxidants to employ against the injury by active

the SE. Bars with the same letter are not significantly different, denoted by $P<0.05$ according to Duncan's multiple range tests

oxygen. Among these are SOD, POD and CAT, which play obligatory roles in this process. It has been reported that ROS scavenging by the enhanced activation of antioxidant enzymes can strengthen salt tolerance (Alscher et al. 2002). Our results showed that superfluous lipid peroxidation occurred progressively in JAs subjected to salinity (Fig. 4), which resulted in increasing membrane permeability as expressed by electrolyte leakage. The process of lipid peroxidation was closely related to the increasing activity of antioxidative enzymes in leaves, and the increment in the electrolyte leakage, which indicated as an elevated amount of MDA content in the plant leaves. Compared with the control, there were significantly increased levels of SOD, POD and CAT activity under $100 \mathrm{mM} \mathrm{NaCl}$, but a prominent reduction under $200 \mathrm{mM} \mathrm{NaCl}$. The levels of MDA in N1 were significantly higher than in M1. Therefore, these results suggested that M1 had a greater capacity of salt resistance than $\mathrm{N} 1$.

Protein is the executor of the physiological function as well as the direct manifestation of biological phenomena (Wilkins et al. 2013). The study of protein structure and function helps clarify changes in physiological mechanisms. Two-dimensional gel electrophoresis (2-D gels) can authenticate the complicated protein samples at the proteome-wide level. Salt tolerance of JA plant consists of complex biochemical pathways including a mass of gene expression, and the application of 2-D gels offers great 

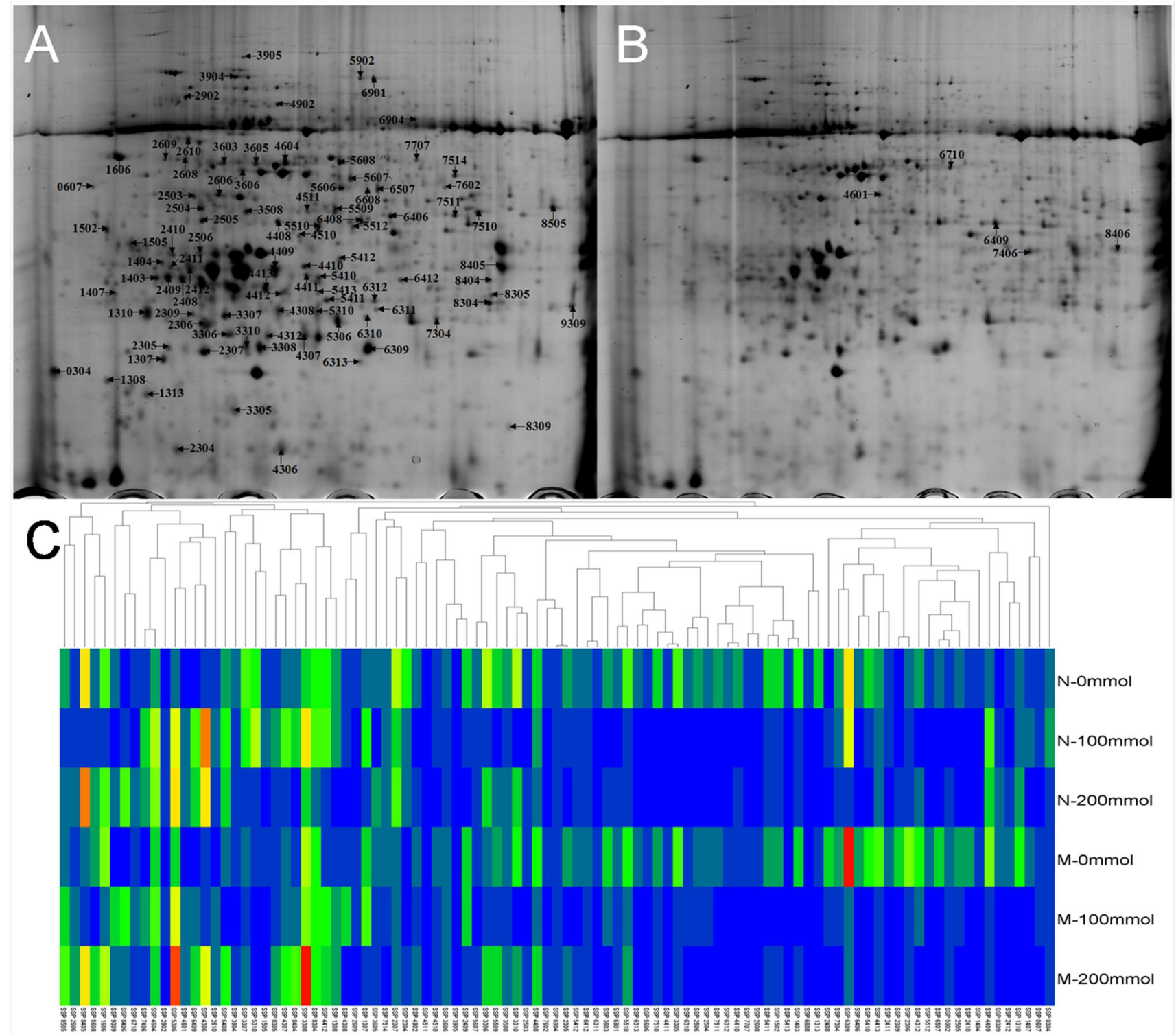

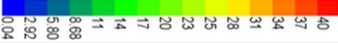

Fig. 5 Large format 2-D gel showed the soluble protein profile of two JA s in A and B. Urea lysis buffer soluble and fluorescently labelled proteins were visualized using the Typhoon scanner. Out of 952 spots seen via argent labelling, after image analysis, 99 were discrepantly responsive between JA s. Conflicting protein expression plot $(>2$ -

opportunities to clarify the process of protein change during salt tolerance. Comparatively, the regulation of protein expression in $\mathrm{M} 1$ was much more positive than in $\mathrm{N} 1$ (Fig. 5), which provided comprehensive insights into differences in adaptation to saline environments between the two JAs.

In the present study, it can be concluded that although the Jerusalem artichoke plant showed a similar salt-tolerant mechanism but with a much larger difference between cultivars. In general, the growth of both JA cultivars was folds, $P<0.05)$ were analyzed and the result was shown in $\mathrm{C}$. Different expressing quantity replaced by various colors. Blue: low content of the protein; red: high content of the protein. A hierarchy was formed by Pearson's square coefficient and calculated by complete linkage

strongly influenced by salt stress. However M1 exhibited a higher salt tolerance than $\mathrm{N} 1$, which mainly reflected in the differences in the water retaining capacity, chlorophyll content and stability of the chloroplast structure as well as osmotic regulatory capability. Penetrating cutting-edge elementary proteomics results further provided comprehensive insights into differences in salt-tolerant adaption for the two JA cultivars.

Acknowledgements This work was partially supported by National Key Research and Development Program (No. 2019YFD0900702), 
An International Workshop on the nexus of food-energy-water (FEWS) systems: U.S.-China (20191J006), and Key R\&D Program of Shandong Province (2019JZZY020614).

\section{Compliance with ethical standards}

Conflict of interest The authors declare that they have no conflict of interest.

Open Access This article is licensed under a Creative Commons Attribution 4.0 International License, which permits use, sharing, adaptation, distribution and reproduction in any medium or format, as long as you give appropriate credit to the original author(s) and the source, provide a link to the Creative Commons licence, and indicate if changes were made. The images or other third party material in this article are included in the article's Creative Commons licence, unless indicated otherwise in a credit line to the material. If material is not included in the article's Creative Commons licence and your intended use is not permitted by statutory regulation or exceeds the permitted use, you will need to obtain permission directly from the copyright holder. To view a copy of this licence, visit http://creativecommons. org/licenses/by/4.0/.

\section{References}

Akhzari D, Sepehry A, Pessarakli M, Barani H (2012) Studying the effects of salinity stress on the growth of various halophytic plant species (Agropyron elongatum, Kochia prostrataand Puccinellia distans). World Appl Sci J 16:998-1003

Alscher RG, Erturk N, Heath LS et al (2002) Role of superoxide dismutases (SODs) in controlling oxidative stress in plants. J Exp Bot 53(372):1331-1341

Ashraf M, Harris P (2004) Potential biochemical indicators of salinity tolerance in plants. Plant Sci 166:3-16

Aslam B, Basit M, Nisar MA et al (2017) Proteomics: technologies and their applications. J Chromatogr Sci 55(2):182-196

Bergmeyer HU, Bernt E (1974) In: Bergmeyer HU (ed) Methods of enzymatic analysis, vol 3, 2nd edn. Verlag Chemie, Weinheim, Academic Press Inc., New York, London, pp 1176-1179

Bhagia S, Ferreira JF, Kothari N et al (2018) Sugar yield and composition of tubers from Jerusalem artichoke (Helianthus tuberosus) irrigated with saline waters. Biotechnol Bioeng 115(6):1475-1484

Bradford MM (1976) A rapid and sensitive method for the quantitation of microgram quantities of protein utilizing the principle of protein-dye binding. Anal Biochem 72(1):248-254

Bui EN (2013) Soil salinity: a neglected factor in plant ecology and biogeography. J Arid Environ 92:14-25

Chen Q, Zhang MD, Shen SH (2011) Comparison of protein extraction methods suitable for proteomics analysis in seedling roots of Jerusalem artichoke under salt $(\mathrm{NaCl})$ stress. Afr J Biotechnol 10:7650-7657

Datta J, Nag S, Banerjee A, Mondai NK (2009) Impact of salt stress on five varieties of wheat (Triticum aestivum L.) $\mathrm{s}$ under laboratory condition. J Appl Sci Environ Manag 13:93-97

Dolatabadian A, Sanavy SA, Ghanati F et al (2011) Effect of salinity on growth, xylem structure and anatomical characteristics of soybean. Notulae Botanicae Horti Agrobotanici Cluj-napoca 3(1):41-45

Duché O, Trémoulet F, Glaser P, Labadie J (2002) Salt stress proteins induced in Listeria monocytogenes. Appl Environ Microbiol 68:1491-1498
Eldakak M, Milad SI, Nawar AI et al (2013) Proteomics: a biotechnology tool for crop improvement. Front Plant Sci 4:35-35

Hernandez JA, Campillo A, Jimenez AI et al (1999) Response of antioxidant systems and leaf water relations to $\mathrm{NaCl}$ stress in pea plants. New Phytol 141(2):241-251

Keiper FJ, Chen DM, De Filippis LF et al (1998) Respiratory, photosynthetic and ultrastructural changes accompanying salt adaptation in culture of Eucalyptus microcorys. J Plant Physiol 152:564-573

Kwak S, Kim S, Lee M et al (1995) Acidic peroxidases from suspension-cultures of sweet potato. Phytochemistry 39(5):981-984

Litchenthaler HK (1987) Chlorophylls and carotenoids: pigments of photosynthetic biomembranes. Methods Enzymol 148:350-383

Long XH, Chi JH, Liu L et al (2009) Effect of seawater stress on physiological and biochemical responses of five Jerusalem artichoke ecotypes. Pedosphere 19(2):208-216

Lu RK (2000) Analysis methods of soil agricultural chemistry. China Agricultural Science and Technology Publishing House, Beijing, pp 112-120

Machado RM, Serralheiro RP (2017) Soil salinity: effect on vegetable crop growth. Management practices to prevent and mitigate soil salinization. Horticulturae 3(2):30

Mahmoodzadeh H, Nabavi M, Kashefi $\mathrm{H}$ et al (2015) Effect of nanoscale titanium dioxide particles on the germination and growth of canola (Brassica napus). J Ornam Plants 3(1):25-32

Mencarelli F, Saltveit ME (1988) Ripening of mature-green tomato fruit slices. J Am Soc Hortic Sci 113(5):742-745

Munns R, Gilliham M (2015) Salinity tolerance of crops-what is the cost? New Phytol 208(3):668-673

Newton PJ, Myers BA, West DW et al (1991) Reduction in growth and yield of Jerusalem artichoke caused by soil salinity. Irrig Sci 12(4):213-221

Roy SJ, Negrao S, Tester M et al (2014) Salt resistant crop plants. Curr Opin Biotechnol 26:115-124

Shabala S, Shabala L, Van Volkenburgh E et al (2003) Effect of calcium on root development and root ion fluxes in salinised barley seedlings. Funct Plant Biol 30(5):507-514

Singh J, Sastry EV, Singh VV et al (2012) Effect of salinity on tomato (Lycopersicon esculentum Mill.) during seed germination stage. Physiol Mol Biol Plants 18(1):45-50

Smart RE, Bingham GE (1974) Rapid estimates of relative Water content. Plant Physiol 53(2):258-260

Tester M, Davenport RJ (2003) $\mathrm{Na}^{+}$tolerance and $\mathrm{Na}^{+}$transport in higher plants. Ann Bot 91(5):503-527

Thiede B, Koehler CJ, Strozynski M et al (2013) High resolution quantitative proteomics of $\mathrm{HeLa}$ cells protein species using stable isotope labeling with amino acids in cell culture (SILAC), two-dimensional gel electrophoresis (2DE) and nano-liquid chromatograpohy coupled to an LTQ-Orbitrap mass spectrometer. Mol Cell Proteomics 12(2):529-538

Tuncturk M, Tuncturk R, Yildirim B et al (2011) Effect of salinity stress on plant fresh weight and nutrient composition of some Canola (Brassica napus L.) cultivars. Afr $\mathrm{J}$ Biotechnol 10(10):1827-1832

Wilkins M, Williams KL, Appel RD, Hochstrasser D (2013) Proteome research: new frontiers in functional genomics. Springer, Berlin

Willekens H, Van Camp W, Van Montagu M et al (1994) Ozone, sulfur dioxide, and ultraviolet B have similar effects on mRNA accumulation of antioxidant genes in Nicotiana plumbaginifolia L. Plant Physiol 106(3):1007-1014

Xue YF, Liu ZP (2008) Antioxidant enzymes and physiological characteristics in two Jerusalem artichokes under salt stress. Russ J Plant Physiol 55(6):776-781 
Yang H, Hu J, Long X et al (2016) Salinity altered root distribution and increased diversity of bacterial communities in the rhizosphere soil of Jerusalem artichoke. Sci Rep 6(1):20687-20687

Yilmaz H, Kina A (2008) The influence of $\mathrm{NaCl}$ salinity on some vegetative and chemical changes of strawberries (Fragaria $\times$ ananssa L.). Afr J Biotechnol 7(18):3299-3305

Zhao GM, Mehta SK, Zhaopu L et al (2010) Use of saline aquaculture wastewater to irrigate salt-tolerant Jerusalem artichoke and sunflower in semiarid coastal zones of China. Agric Water Manag 97(12):1987-1993

Publisher's Note Springer Nature remains neutral with regard to jurisdictional claims in published maps and institutional affiliations. 